\title{
Intellectual capital management in public universities?
}

Book or Report Section

Accepted Version

Michalak, J., Krasodomska, J., Rimmel, G., Sort, J. and Trzmielak, D. (2017) Intellectual capital management in public universities? In: Guthrie, J., Dumay, J., Ricceri, F. and Nielsen, C. (eds.) The Routledge Companion to Intellectual Capital. Routledge. ISBN 9781138228214 doi: https://doi.org/10.4324/9781315393100.ch10 Available at https://centaur.reading.ac.uk/73610/

It is advisable to refer to the publisher's version if you intend to cite from the work. See Guidance on citing.

To link to this article DOI: http://dx.doi.org/10.4324/9781315393100.ch10

Publisher: Routledge

All outputs in CentAUR are protected by Intellectual Property Rights law, including copyright law. Copyright and IPR is retained by the creators or other copyright holders. Terms and conditions for use of this material are defined in the End User Agreement.

www.reading.ac.uk/centaur

\section{CentAUR}


Central Archive at the University of Reading

Reading's research outputs online 


\section{Intellectual capital management in public universities}

Jan Michalak*, Joanna Krasodomska ${ }^{\wedge}$ Gunnar Rimmel ${ }^{+\#}$, Jesper Sort ${ }^{\circledR}$, Dariusz Trzmielak*

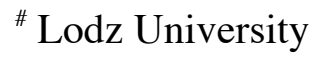

${ }^{\wedge}$ Krakow Economic University

${ }^{+}$Gothenburg Research Institute

\# Jönköping International Business School

${ }^{\circledR}$ Business Model Design Center at Aalborg University in Denmark

\section{Postal address:}

${ }^{+}$Wydzial Zarzadzania

Lodz University

Matejki 22/26

90-237 Lodz, Poland

E-mail: jmichal@uni.lodz.pl

September 2016 


\begin{abstract}
The purpose of the chapter is to present the concept of intellectual capital in knowledge intensive organisations - public universities. Recently, public universities have been increasingly undertaken intellectual capital management activities in order to face environmental pressures such as shortage of funds, students deficiency, and challenges connected with the globalisation of educational market. What is more, they ceased to be regarded only as centres of education and research, but also as entities which cooperate with business and other stakeholders in order to commercialise the research results.
\end{abstract}

The chapter draws attention to the New Public Management influence on intellectual capital management, its advantages and strains. It also discusses the universities' intellectual capital structure (human, structural (internal) and relational) and its' measurement methods, such as the Austrian Wissenbilanz, the Observatory of European Universities ICU Report, and the Intellectual Capital Maturity Model (ICMM).

The intellectual capital is a prominent source of university's competitive advantage. The chapter presents the main sources of this advantage, as well as describes the way the university intellectual capital can be linked with its market value. It discusses the knowledge commercialisation process which generates intellectual capital in a university, providing it with not only scientific and educational value but also market value. In the chapter, the benefits of collaboration between universities and industry are presented. The universities-industry collaboration offers researchers the possibility to enhance the value of their intellectual capital by monetary or contextual research support, which contributes to their higher scholarly productivity. As for students, it allows them to gain work practice, learn to apply theoretical learnings in practice and assess business needs. Apart from motivation from the government and benefits for the both sides, there are also some barriers to successful collaboration between universities and industry, which are also discussed in the chapter.

The chapter makes an attempt to contribute to the intellectual capital debate by providing some insights into the way it is understood, measured and managed in specific entities - public universities. Authors call for more research in this area, which could focus on activities and skills needed to manage intellectual capital at universities in a successful way, as well as on the 
processes of its' creation and commercialization. They also refer to the third stage of intellectual capital research, which concentrates on how its measurement and reporting is used for the management purposes on various levels (?). 


\section{Introduction}

Traditional universities management is closely related to what is thought of as being the longestablished values of universities. A definition given by Dearlove (2002, p.) describes traditional university values: "Universities are essentially seen as communities of scholars where research, critical thought and the dissemination of knowledge takes place." The quotation from Dearlove (2002) describes the fundamental values of a university consisting of knowledge creation and knowledge edification. Therefore, university management needs to support and promote their researchers enabling to do so. University management, considering the traditional values, would, for example, focus on promoting academic freedom and autonomy for the researchers (Kok et al., 2010). One specific feature of public universities management is that the composition of research communities of scholars is in most cases they are governed and managed by collegial bodies consisting of researchers.

Universities are distinctive from other educational institutions given their power to award academic degrees. This power enables the researchers at universities to have freedom of inquiry and lecturing with a purpose of seeking and further communicating truths found in their research (Kok et al., 2010).

Hence universities are regarded as centres of excellence both in education and research which they compete on in attracting students and staff from all over the world. However, the original values and goals of knowledge generation, progressive inquiry, thought and debate may be overwhelmed by new pressing issues of quantified quality (Bowden and Marton, 1998). In consequence, the values of universities are changing (Van Dierdonck et al., 1990; Mouwen, 2000; Kok et al., 2010).

More recently, in addition to research and education, a third role of Universities has emerged. The third role includes cooperation with business and other stakeholders together commercialisation (or in wider sense valorisation) of research results. The importance of the third role increased together with the New Public Management movement (Dearlove, 2002; Pollitt, 2002) and the proliferation of a Triple Helix concept of university-industrygovernment relations (Leyersdorf and Etzkowitz, 1996). There exists a general tendency in the OECD countries to enforce the third role activity by law to induce collaboration. Policy makers aim at involving all higher education institutions as partners in a nationally balanced socio- 
economic strategy. Findings by Hazekorn (2005) explains that in recent years more governments have begun to think strategically about the economic significance of academic knowledge production, asking how higher education can be restructured to become a more effective and efficient economic actor. The tendency influences how universities are managing their intellectual capital.

"Among the key principles of the entrepreneurial university, the engagement of multiple stakeholders for the achievement of the "third mission" is today more pressing than in the past. Universities - and in general all higher education institutions - have moved from focusing exclusively on their traditional twin missions of teaching and research, towards a more active role for economic and cultural growth, the so called third mission (Etzkowitz et al., 2000; Vorley and Nelles, 2008). Generally, third mission activities comprise three dimensions in which universities engage externally: technology transfer and innovation; continuing education; and social engagement. This has been motivated by stakeholders' demand for greater transparency, increasing competition between universities and firms, greater autonomy, and the push by universities towards the adoption of new management and performance systems that incorporate intangible assets and IC (Sánchez et al., 2009; Secundo et al., 2010, 2015; Secundo and Elia, 2014). In the last decade, there has been a growing interest in applying an IC approach in universities (Leitner, 2004; Sánchez and Rivera, 2009; Brătianu, 2009; Nava and Mercado, 2011; Veltri et al.,2014;Wu et al., 2012), since their main goals are the production and the diffusion of knowledge and their more important investments are in research and human resources (Elena 2004; Pircher and Risku, 2005; Sánchez and Elena, 2006). Ramirez et al 2016 p. 177)"

Public universities have been facing major challenges in the second decade of the twentiethfirst century. The global financial crisis and resulting from it increase of public debt decreased public funding of both research and education. At the same time, the demographic downturn in many European countries has led to the lower number of students and more competition on the global educational market.

"The European Union appears to have been particularly stricken by austerity, as European member states have been required to adhere to new governance parameters, comply with fiscal compact rules, accept debt consolidation processes, pursue balanced budgets while still being expected to respect Maastricht treaty requirements." Humphrey 2015, p. 882 
Increased international students' mobility generated increased global-scale completion among universities. In such setting management of universities and especially management of their intellectual capital gains particular importance.

Universities management cannot be abstracted from the whole ecosystem of their stakeholders. Burrows (1999) identified a wide range of universities' stakeholders: governing entities (state and local government), administration (rector/ senior administrators) employees (faculty, administrative staff; support staff), clients (students; parents/spouses; tuition reimbursement providers; service partners; employer), suppliers (secondary education providers; alumni; other colleges and universities; food purveyors; insurance companies; utilities; contracted services), donors, communities, regulators (both governmental and non-governmental), financial intermediaries, competitors and joint venture partners. In the group of competitors, he distinguished direct ones - existing providers of post-secondary education, potential ones distance providers and new ventures and substitutes i.e. employer-sponsored training programmes. As universities resources became increasingly dependent on market decisions (like starting and pricing new educational programmes and research projects) and allocations based on metrics rather than institution oriented grants, they are forced to decide how prioritise and how to reconcile contradictory interests of stakeholders (Slaughter and Leslie 2001). Benneworth and Jongbloed (2010) stressed that in order to manage universities their governing bodies should develop and in some cases influence the ranking of stakeholders based on the salience of their impact. Well-developed intellectual capital management system should include the impact of stakeholders and facilitate cooperation with them (Secundo et al., 2015)

Following Dumay and Garanina (2013) call for third stage of IC research more investigation is needed in the area of how IC measurement and reporting is used for managing IC at the level of departments, universities, research consortia, countries and whole European Union.

This Chapter explores the following four research questions:

(1) How New Public Management influences Intellectual Capital Management?

(2) What are the factors influencing the Intellectual Capital value at the universities and business relation? 
(3) How is Intellectual Capital measured and managed in universities from the viewpoint of various stakeholders constituting universities' ecosystems?

(4) What is the Role of Intellectual Capital in knowledge transfer?

"The evolution of IC research can be traced as organised into four main stages. Originally, Petty and Guthrie (2000) outlined two stages associated with developing IC as a research field. The first stage of IC research focused on raising awareness and understanding IC's potential for creating and managing a sustainable competitive advantage in private organisations. This stage is grounded in the work of practitioners in the 1980s and 1990s. The main focus was the awareness of IC as something significant to be measured and reported, but with little empirical research provided in support (Petty and Guthrie, 2000). In contrast, during the second stage, IC was established as an approach related to strategic management and evidence was gathered to justify its use (Petty and Guthrie, 2000, pp. 155-156). In this stage, a plethora of IC frameworks were applied in practice to demonstrate their potential value creation impacts. Different classifications were created, which helped to define and group different methods of IC evaluation (Boedker et al., 2008; Ricceri, 2008). As a result, by the mid-2000s, more than 50 methods were created (Pike and Roos, 2007; Sveiby, 2010). Later, a third stage of IC research gained impetus to study how organisations understand, adapt and apply IC as a management technology (Guthrie et al., 2012), especially in cases of attempting to manage IC for the first time. Advanced models developed in the third stage adopted the evolved notion of IC as a dynamic system on intangibles resources based on knowledge (Veltri et al., 2014). In these kinds of models, attention is focused on the interactions between the IC components and intangible activities essential in the production, maintenance and development of intangible resources (Silvestri and Veltri, 2011). The assumption behind these models is that measurement of IC is necessary for the management of knowledge, and their main aim is to identify the paths of an organisation's value creation based on knowledge (Veltri et al., 2014). Some features are considered relevant when analysing and defining an integrated IC management model: the potential value of IC, its dynamic and the organisation-specific nature. Dumay and Rooney (2011, p. 344) found "that it is possible to effectively implement IC practices without necessarily needing concrete IC measures because organisational measurement needs continually evolve depending on factors such as the characteristics of individual organisations; changing internal and external political, social and economic environments; and evolving business plans and strategies". Another essential aspect of the third stage is empirically researching IC practices inside organisations rather than IC measures (Guthrie et al., 2012). 
Other researchers have highlighted the need for reporting and disclosing IC both to internal and external stakeholders, underlining the link with stakeholder theory and legitimacy theory (Guthrie et al., 2006). These assumptions form the basis of a further stream of research often identified as the fourth stage. (...) “

The remainder of the chapter is organised as follows. The Section 2 presents how New Public Management influences intellectual capital management at universities. In Section 3 the specific structure of intellectual capital at universities is outlined, as well as different Intellectual Capital measurement methods. Section 4 discusses the measurement ... Thereafter, in Section 5 the relation between Intellectual Capital measurement and competitive advantage and knowledge commercialisation is described. Section $6 \ldots$ The chapter concludes with current accomplishments at the studied universities and suggestions for further research.

\section{New Public Management and Intellectual Capital Management at Universities}

The change in the contextual factors means that universities, regardless of type, have experienced the effects of managerialism and new public management (NPM) (Dearlove, 2002; Pollitt, 2002). In other words, where welfarist ideals of learning and education as a public good may have been surpassed by the new needs of profitability and competitive survival (Bok, 2009). The terms of profitability, operational efficiency and competitive survival are wellknown aspects of running a company, but not accordingly to the traditional values of universities, therefore NPM inevitably has been changing management approaches at universities.

The introduction of NPM in universities showed positive results in many cases. Advantageous effects embraced: ensuring control, promoting, accountability, and assessing performances, ultimately establishing a stricter and more scrutinised form of administration. Such notions facilitated also cooperation of universities with stakeholders originating from business realms, which are used to follow similar principles. However, at times, the results have had severe strains and considerable effects on academic freedom and autonomy (Davies and Thomas, 2002). In turn, NPM is also believed to force the academics to engage in industry collaborations further diminishing their freedom and forcing more applied science to be conducted at the cost 
of basic research. The effects thus are far from being clear but in the university setting various negative effects appears among others contributions from universities to the outside world are limited (Bogt and Scapens, 2012). However, other studies showed the increased collaboration with the industry has not led to less basic research being conducted (Van Dierdonck et al., 1990).

Some critics argue that NPM - and the ideologies of performance measurement generallysimply are incompatible with the culture and mission of the public sector (Cavalluzzo and Ittner, 2004). The fear is that the traditional performance measures of companies are not applicable at universities as measures like lecturing hours and publications are indirect measures and not showing real implication on knowledge generation and knowledge transfer to society (see for example Bogt and Scapens, 2012).

Advocating for a different approach is rising from believers that Intellectual Capital creation is still the main goal for universities and hence should not follow the corporate measures and management styles (Warden, 2004). The advocates of Intellectual Capital are encouraging instead approaches from knowledge management to ensure the production and diffusion of knowledge (Elena, 2004; Secundo et al., 2015). Even though no "one solution fits all" have been found different ideas have spurred from these directions on how to manage universities. The ambition of knowledge management approach being to let knowledge work to create value (Roberts, 1999; Kianto et al. 2014).

The knowledge management and intellectual capital management style is an approach with emphasize on identifying and valuing the knowledge assets at the universities and raise these assets through knowledge sharing and creating new knowledge (Holsapple, 2003). Adopting the management should assist in measurement, management and diffusion of knowledge to improve transparency (Elena, 2004). The ambition of the management approach being to identify and support the knowledge assets of the university being, for example, the researchers to show the value of their knowledge. This identification hence will help illustrate the assets and to communicate their value to external stakeholders (Warden, 2003). Opposite to NPM, the idea is to enable an understanding of the knowledge value for the stakeholders ecosystem rather than accepting measures of traditional companies. In other words, identifying and communicating the knowledge value rather than showing a positive bottom-line. 
The implementation of various knowledge management approaches has been studied with different perspectives and in various countries. For example, Secundo et al. (2015) proposed an intellectual capital maturity model as a management alternative for universities (see more in the Section 4).

While discussing the management styles influencing the universities, it is worth to refer to the concepts regarding the application of private-sector notions of performance measurement to non-profit organisations. It should be stressed that before transferring management tools derived from a for-profit to a non-profit organisation, it is necessary to identify whether the assumptions underlying the certain model of the former and its environment are also adequate for the latter. If not, they must be adjusted (Speckbacker 2003). Speckbacker (2003) presents three economic models of the firm and discusses them with respect to their adequacy for nonprofit organisations. While the first two hold interesting points of views the third model is of special interest in the setting of universities (for further about the first two see Speckbacker, 2003).

The third model presented by Speckbacker (2003, p.274), The Modern Stakeholder View of Organizations, is a model under which a firm is understood as a combination of mutually specialized assets and people. It is a connection of incomplete contracts, and the corporate nature and success depends on the importance of specific investments, which needs to be managed. Balancing the contributions of all stakeholders against their share and hence determining the extent to which implicit claims are fulfilled is the core of performance measurement under this approach. Incomplete contracts and specific investments, are transferable to nonprofit organisations. For example, university employment contracts usually state initial wages and other conditions but are incomplete with respect to other issues, such as the conditions for layoffs or promotions or timing and manner of determining wage increases. Students pay not only for the education, but also for implicit claims on service and further support that are not legally enforceable (e. g. being a member of the alma mater community). Likewise, universities may invest in graduates' relations in the hopes of gaining their loyalty, or creating conditions for future university-industry collaboration. Performance measurement system has to provide information about the nature of university stakeholders' claims, and it has to define trade-offs in case of conflicting claims. 
Universities are also organisations, which use more and more often technology from external sources. Cooperation, as well as horizontal and vertical networking have gained importance and are an important change in strategic management (Edler et al., 2002, p. 161). A business network is understood as a set of two or more connected business relationships, in which each exchange relations is between business firms that are conceptualized as collective actors (Emerson, 1981; Anderson et al., 1994). According to Sopińska (2014), knowledge management and intellectual capital management in a network organisation should be carried out simultaneously at two levels: the level of the entire network and the level of a single link of the network. A knowledge management model should comprise: the identification of the applied knowledge management strategy, a description of the knowledge exchange process, and a measurement of the level of the process formalisation and centralisation. In the case of universities, networks are formed through government, individual, and department strategic initiatives (Jarratt et al., 2014). The findings show positive impact on the intellectual capital as the knowledge sharing occurring during networks allowing complex research and for "weaker" universities to contribute with their particular knowledge. ${ }^{1}$

\section{Knowledge and Intellectual capital in Universities}

The components of a university's Intellectual Capital have been categorized in diverse ways. According to Ramírez and Godrillo (2014) the tripartite classification is the most widely accepted in the literature (Leitner, 2004; Ramírez et al., 2007; Sanchez et al., 2009; Bezhani, 2010; Casanueva and Gallego, 2010; Secundo et al., 2010). Relatively rarely customer capital is distinguished (Kok, 2007). The three main components of the IC are now presented.

First, human capital is defined as the sum of the explicit and tacit knowledge of the university staff (teachers, researchers, managers, administration and service staff), acquired through formal and non-formal education and processes included in their activities. In other words, this is the knowledge that employees take with them when they leave the university. Examples of the human capital include: innovation capacity, creativity, know-how and previous experience, teamwork capacity, employee flexibility, tolerance for ambiguity, motivation, satisfaction, learning capacity, loyalty, formal training and education (MERITUM, 2002 p. 10). 
Second, structural (internal) capital understood as the explicit knowledge relating to the internal processes of dissemination, communication and management of the scientific and technical knowledge at the university. Structural capital may be divided into organisational capital and technological capital (Corcoles et al., 2011; Ramírez, Godrillo, 2014). Organisational capital is the operational environment derived from the interaction between research, management and organisation processes, routines, culture and values, internal procedures, quality and scope of the information system, etc. Technological capital includes the technological resources available at the university, such as bibliographical and documentary resources, archives, technical developments, patents, licenses, software, databases, etc.

Third, relational (external) capital is defined as all resources linked to the external relationships of the institution such as customers, suppliers, R\&D partners, government. It also includes the perception that others have of the university. Examples of this category are image, students and other partner's loyalty and satisfaction, links with suppliers, commercial power, negotiating capacity with financial entities, environmental activities, etc.

Within each category of the Intellectual Capital we can differentiate between resources and activities. MERITUM (2002) defines these two categories as intangible resources (static notion) and intangible activities (dynamic notion). Both can be presented with the use of financial and non-financial indicators. Intangible resources are understood as the stock or current value of a given intangible at a certain moment in time. They may or may not be expressed in financial terms. The resources can be both inputs (researchers, for instance) or outputs (publications). The intangible activities imply an allocation of resources aimed at: developing internally or acquiring new intangible resources, increasing the value of existing ones, or evaluating and monitoring the results of the former two activities (Sánchez et al., 2006).

In order to measure and manage the above mentioned types of categories of capital the analysis of universities stakeholder's ecosystem is useful. Large, long-lasting universities in capital cities tend to have a stronger relational capital due to easier access to stakeholders including state and local government, wide range of employees, students, big employers, regulators and joint venture partners. Such advantage enables them to enhance their structural and human capital. Such universities are in privileged position in acquiring best researchers, "celebrities lecturers" due to their budget, reputation and short distance to headquarters of large corporations, tv stations and regulators. Superior infrastructure around them (including better 
IT infrastructure, laboratories, datacentres) enables them to expand their structural capital. However, such universities face also more severe competition for some intangible resources (especially postgraduates who have more, well paid careers paths around them).

\section{Measuring and disclosure the university knowledge by diagnostic intellectual capital}

Measuring and disclosure of intellectual capital is a widely researched and discussed topic especially in the second stage of Intellectual Capital research (Petty and Guthrie, 2000, Guthrie et al., 2012, Michalak, 2012, Dumay and Garanina, 2013). In the course of dissemination of intellectual capital concept universities have tried to apply methods of intellectual capital measurement developed in the business environment including Balanced Scorecard (Kaplan and Norton, 1996; Kaplan 2001 Philbin, 2011), Skandia Navigator and the Skandia Value Scheme (Kok, 2007).

Later a growing number of intellectual capital measurement and reporting methods were developed specially for universities. Examples of such methods are Intellectual Capital Report of the Austrian Research Centre (Wissenbilanz developed and implemented in Austria) ICU Report proposed by Observatory of European Universities (Sanchez and Elena, 2006).

The Wissenbilanz is a sustainable case of intellectual capital reporting. In 1999, the Austrian Research Centers, Seibersdorf, was the first European research organisation that published a Wissenbilanz for the entire organisation (Leitner and Warden, 2004). Shortly after, Act on Organisation of Universities made Wissenbilanz Compulsory for Universities in Austria. The structure of the Wissenbilanz and the detailed list the were published in February 2006 (Altenburger et al., 2006) and were updated later.

Austrian Wissenbilanz consists of number of indicators organised in the typical IC categories (human, structural and relational). It also presents measures its core process - strategic research, contract research and cooperative research as well their results. The indicators included in the Austrian Wissenbilanz embrace among others:

1) In category of Human Capital: Number of researchers, Proportion of research staff (\% headcount), New employees hired - total Full-Time Equivalents, Women in senior positions (\%), Total training days per employee 
2) In the category of Structural Capital: Capital investment (\% of operating revenues), Capital investment in large research equipment, laboratory floor space

3) In the category area of Relational Capital: Number of international researchers, Number of international $\mathrm{PhD}$ students

4) In the area of Core Processes (Research): Funding for strategic research, Number of projects with project volume $<70.000 \mathrm{EUR}$,

5) In the area of Results Total income from contract research in '000 EUR, Orders intake from industry (in \%), Publications in peer-reviewed journals with Citation Index, Dissertations completed (Measures taken from IC Report of Austrian Institute of Technology 2012).

Similar measures are used for universities evaluation in other European Union Countries (Geuna and Martin, 2003). A common tendency in universities evaluation is to increase the importance of revenues from cooperation with business. It reduces universities dependency on public funding and helps to make the country economy more innovative. It can create a problem for some universities, as it promotes applied sciences and technical universities (Benneworth and Jongbloed, 2010).

Austrian Wissenbilanz also embraces a narrative part covering University structure and commentary on obtained results (see, Austrian Academy of Sciences Intellectual Capital Report 2012). Austrian Wissenbilanz is used also for internal management purposes. For those purposes it is used to produce disaggregated indicators and goals (Leitner and Warden, 2004). Latter studies results showed that Wissenbilanz is systematically coupled with strategic management process but it not fully utilized as a strategic tool (Wiedenhofer, Bornemann 2016).

The mandatory nature of Austrian IC report has both advantages and disadvantages. The advantge of mandatory IC reporting are: the possibility of benchmarking among universities, the proliferation of IC models world-wide, improvement in the development of the of public policies and increase transparency in the whole system (Avkiran, 2006). The disadvantage of mandatory approach may be the tendency to focus only on the measures that are mandatory disregarding important aspects or processes that would have been developed otherwise (Altenburger et al., 2006). Leitner (2004), quoting Davies (1999) warns even about "goal displacement", where the focus on performance-based assessment results in efforts towards 
meeting the requirements and not satisfying the institution's aims. Moreover, Leitner and Warden (2004) warn that use of Wissenbilanz for both external reporting and internal management may lead to concealing information that will have negative consequences for their funding.

The Observatory of European Universities was created in June 2004, and its aim was to provide universities and research centres with the necessary tools and instruments for the governance of research activities (Sánchez and Elena, 2006, p. 538). Universities and research institutes from various European Countries were involved in this project (Germany, Spain, France, The Netherlands, Hungary, Italy, Portugal and Switzerland) (Dima, 2014, p. 36). The project run till November 2006 and its main outcome was a Methodological Guide about research measurement (Elena and Leitner, 2013, p.134-135).

Observatory of European Universities identifies five "thematic dimensions": funding (all budget elements, analysing revenues and expenses), human resources (administrative staff, researches/teachers and $\mathrm{PhDs}$ ), academic production (results from research activities in all fields, i.e. articles, academic publications, non-written results, and the knowledge embodied in $\mathrm{PhDs}$ ), third mission (all the activities and relations between universities and non-academic partners, i.e. firms, non-profit organisations, public authorities, local government, and society as a whole), governance (the process by which the university converts its inputs (funding and human resources) into research outputs (academic outcomes and third mission)). It also distinguishes the "transversal issues" which are: autonomy, strategic capabilities, attractiveness, differentiation profile, territorial embedding. As a result of the interactions of the aforementioned issues, a "strategic matrix" is created in which, in each cell, various key questions and a set of indicators are included.

As a part of the Observatory of European Universities initiative, a ICU Report was developed, a set of specific recommendations for European Universities ((Elena and Leitner, 2013, p.135). It aimed at making the disclosure of IC information on research activity of European Universities more homogenous. According to the framework, ICU Report should consist of three sections: university's vision, summary of intangible resources and activities, and a system of 43 financial and non-financial indicators related to human, organisational and relational capital. 
University's vision expresses its ambition to increase the value a user receives from the services provided by it. This (first) section is also called the knowledge narrative (Sánchez et al., 2006, p. 230). The second section, a summary of intangible resources and activities, presents the intangible resources the institution can mobilise and the different activities are undertaken to improve their value. In the third section, a system of indicators is proposed. The indicators allow to compare the universities achievements among institutions (in space), and over time, which is useful to both external parties and management. While compiling a list of indicators, OEU initiative was considered as a starting point. From the 141 indicators that the OEU Matrix had, only 43 were pre-selected. In this process strategic objectives, availability of data and perceived willingness to disclose and checking against the MERITUM characteristics were taken into account.

The researchers participating in Observatory of European Universities identified the following barriers in the IC measurement and disclosure within a university context. First, no regulations, standards or norms related to preparing IC reports at national level were established by accounting bodies or government agencies. Second, not all universities are at the same stage of development. Third, there exists huge diversity if institutions across Europe and immense diversity of models and initiatives. Fourth, different definitions of strategic goals are used across universities. Moreover, most of the European universities follow a functional and disciplinary internal structure, which makes it difficult to manage university research activity as a whole. It results in a large differentiation between departments and makes extremely hard to manage IC in humanistic departments and applied sciences departments. Fifth, most managers of individual faculties have little knowledge about research activity in other disciplines. Sixth and finally, IC measurement is hindered by typical departmental structure of universities its consequence a large differentiation between departments (ie. humanistic departments and applied sciences departments) and problems.

In order to capture a dynamics of intellectual capital management the intellectual capital maturity model (ICMM) was developed (Secundo et al., 2015). Experts eight different European countries (Austria, Greece, Italy, Latvia, Lithuania, Poland, Romania, Spain) proposed model based on seven levels of maturity: data collection, awareness, adjustment, measurement, reporting, interpretation and decision making, strategy and planning. At Level 0 collection activities are aimed at gathering and standardising data. At level 1 university governing bodies identify key intangible assets of a university. At level 2 - adjustments of 
monitoring system are conducted in order to identify the intangible assets that are most important for stakeholders. Measurement of IC (Level 3) requires systematic collection of ex ante defined measures. At the next level a complete report on IC is prepared and publicized. The report should be based on previous activities as well as institutional pressures derived from laws and regulations of the country where the university is located. Interpretation and decision making activities are undertaken at level 5 . They can be conducted by various stakeholders including: faculty and researchers, the technicians, the university board, the local public institution and the national funding. Strategy and other plans based on the previous activities through the lens of intellectual capital assets dynamic is performed at final sixth level. It should focus on the more efficient use of the most valuable assets (Secundo et al., 2015).

\section{Intellectual capital value for stakeholders and competitive advantages}

University intellectual capital is created in many universities mainly based on scientific research that aims to discover new fields of knowledge and their application, (e.g. in new technologies). As Betz (1997) argues, the nature of work on University technologies embraces solutions at a very early stage of technology and product life cycle. Knowledge and university technologies are often completely new to the market, which could build a competitive advantage for both universities as well as for potential buyers of this knowledge. However, researchers at universities consider market potential and competitiveness of created knowledge to much lesser degree, then is done in industry. Therefore, universities have to additionally build specific knowledge and sources of competencies, to be able to cooperate with business and companies and to apply university technologies in industry (Mazzoleni and Nelson, 1998). Intellectual capital at universities should be built so that following players can compete on the market: the university itself as an institution, scientists, and buyers of knowledge and technology created in universities (e.g. students, entrepreneurs). The basic condition of utilisation of transferring scientific research into intellectual value is generating the competitive advantage based on values important for potential buyers. Market approach is of great importance in transferring basic research into applied research, and then into development works, and finally during their implementation. Hendriks and Sousa (2012) stress that the intellectual capital is not only a sum of organisation members' knowledge but also, perhaps first of all, a knowledge transfer. Knowledge transfer from university stakeholders produces real intellectual capital value and 
competitive advantage. Additionally, relational capital is build, which creates ability for the buyers of the knowledge to compete on the market. Consequently, scientists should think about creating added value of the research results for the buyers of knowledge, since the very beginning of the project. Then, the simultaneously generated scientific and commercial value enables the potential buyers and the organisation itself to compete on the market. The value of research work is determined by: method of implementation or granting a license, value of publication from given organisation, expert knowledge of the scientists and students on the market. The basic features of the competitive advantage of intellectual capital result from: specialist market orientation of knowledge; understanding of stakeholders; incubation of technology after assessment of its market potential; professional presentation of research results to the ecosystem of university stakeholders; researchers' awareness of the added value for the target market before demonstrating and promoting the knowledge and technology in the market (Trzmielak, 2013).

The focal point of university management is that the intellectual capital is a prominent source of the competitive advantage. Viewing people, scientific research, and knowledge building as a cost center is a fallacy that does not lead to competitive position (Holton and Yamakovarenko, 2008). The specialisation of knowledge makes the organisation intangible assets unique. It increases the intellectual capital value on the marketplace. The conception of innovative knowledge may be an individual activity (human capital), implementation new knowledge (know-how) is a collective achievement (structural capital) through the social networks (Mura et al., 2012). Specifically, we identify the understanding of stakeholders as the crucial point of network. An external and interactive network knowledge (relational capital) is necessary to exploit innovative market potential. Coherently with needs of market potential assessment, competitive advantage is effected by the demonstrating of knowledge of individuals or organisation. The final challenge in defining the intellectual capital value and competitive advantage is recognizing the intellectual capital value added value before the promoting knowledge and technology on the market. The key to realizing value of intellectual capital is to make sure that individuals and organisation enjoy a long presence on the market and create the long term value (Jolly, 1997).

Currently, new products and services developments are characterized by the high degree of novelty. Highly novel and unique products derive from the key sources of innovations. In this sense, intellectual capital aggregates these sources of innovations (Delgado-Verde, 2016). They 
can be considered to be a fundamental base in creating national and international competitive strategy. The mentioned above features help to allocate intellectual capital at university, to use the intangible assets (knowledge and intellectual property) intensively at the competitive market (Yassen et al., 2016) and differentiate university performance (Koçoğlu et al., 2009).

\section{Linking the University intellectual capital with market value - commercialisation of knowledge}

Universities face enormously difficult, complex decisions when commercializing university research results in economic perspective. Changes that universities had to undergo (their role was not to pass the knowledge, but to discover knowledge and inspire students to apply the laws of science in their thinking) and focusing of science and higher education sector on the market, facilitate the introduction of knowledge commercialisation tools to the scientific research. Usage of knowledge commercialisation tools generates intellectual capital in a university, which does not only have a scientific and educational value but also a market value. Changes within university towards marketisation of the university intellectual capital did not take place at the same pace as changes in the environment of scientific centres, requiring the universities to be opened to the needs of industry and innovative business support institutions. The way of thinking of researchers and other university staff cannot be changed in few days. It is not easy to introduce changes within university even if there exists determination to make changes, as creation of new specialisations requires scientific research and time. This creates a network of dependency, where the pace of building intellectual capital is dependent on the market value. Additionally, the authors of scientific research and technologies see the world very differently from entrepreneurs.

Dubinskas $(1988$, p.) describes the basic differences between entrepreneurs and authors

of ideas for university knowledge. "Realistic businessmen when facing challenges of the market have to deal with dreamers, who try to turn economically unfit ideas into future wealth of companies". The basic goal of a scientist is creation of knowledge and research results that are new, revolutionary and allow for better understanding of the world. Not only people and their philosophy of academic thinking and communication need to foster the idea of building intellectual capital with market value, but also legal and financial conditions, as well as specifications of system and structure (Potwora, 2011). University intellectual capital with the market value changes the general scheme of thinking in traditional universities, which assumes 
that trials of commercializing research results and preparing research project in cooperation of scientists and entrepreneurs contradict the rules of scientific work. Looking for applications of research results in industry can no longer be something unsuitable for representatives of the academia (Matusiak, 2006).

An idea for scientific research does no longer have to be only an intellectual concept, but it should also meet requirements and needs of the market. Wissema (2009) provides numerous reasons for universities to create intellectual capital with market value. They include: massive increase in the number of students, globalisation, interdisciplinary research, increase in the costs of revolutionary research, global culture which facilitates entrepreneurship (Wissema, 2009). Education became a commodity and many students seek opportunity for better employment. Finding a better job is a way of "individual intellectual capital commercialisation". Globalisation brought about competitiveness of universities and they became subjects of the education market. Revolutionary research is more and more often generated in result of combining knowledge and experiences of scientists from different fields (e.g. nanotechnologies emerge from combination of physics, chemistry and biology), and that is why they are increasingly expensive. Financing of research requires both public and private funds. The global culture made students not only seek employment in companies, but also made them create their own businesses. Therefore, there exists a deep sense in building the value of intellectual capital based on market value.

Within changes directed towards utilizing research results, it is necessary to introduce mechanisms of knowledge and technology commercialisation that will make it possible to bring together centuries-old academic traditions, freedom of research, culture generating functioning with market rules where companies operate (Etzkowitz, Webster 1998; Viale, 2010, Matusiak and Guliński, 2010). Although questions that Matusiak proposes "Is university an institution that should compete with other enterprises and institutions on the market, or should it guard the traditional academic values, which are far from the market and commercial thinking?" are still valid.

The answer to above question is proposed by Gross and Allen, $(2003$, p.) "Technology companies need new discoveries ... the cost of basic research program is formidable and its value is difficult to assess". The entrepreneurs require university intellectual capital to equity exchange and need a well-defined university knowledge and technology licensing or 
acquisition. Nevertheless, they need to minimize invention risk and commercialisation costs. The university and company linkage is deal creation (Pogue et al. 2014). Furthermore, business may create significant incentives to engage scientist in scientific projects and educational relationships.

From the perspective of the researcher, there are several possibilities of increasing the value of his/hers intellectual capital. Given the assumption the intellectual capital can be mobilised the primary objective of a researcher could be considered to gain scientific reputation, business and policy-making, having an impact on society and publishing in scientific journals (see further, Siegel et al., 2003; Bruneel et al., 2010). Lee (2000) points out that collaborating with industry often gives researchers access to valuable research data and external funding. Furthermore, collaborations have the possibility of enabling the researcher to test the application of theories and the conceptuality of the ongoing research (Carayol, 2003). The universities-industry collaboration hence offers a way for the researcher to enhance the value of hers/his intellectual capital by monetary or contextual research support.

The notion of researchers aiming at achieving publications in scientific journals can be treated as an indicator of commercialising (valorising) their knowledge as well. Research show different directions on how to improve that, where a study by Siegel et al. (2003) emphasise that researchers who are collaborating with companies have a higher scholarly productivity. Furthermore, researchers have the possibility of directly commercialise their own intellectual capital through spin-offs or patents, indicating the most direct measure of the possible value of the knowledge. Even though this option is not always easily obtained as generating knowledge and commercialising it may occur two very different things (Zucker et al. 2002; Boehm and Hogan, 2014).

Students view their value of intellectual capital somewhat differently as researchers do. Students often want to commercialise their intellectual capital through employment after finishing their education. This can be done through university-business collaboration as this allows the students to gain work practice, learn to apply theoretical learnings in practice and assess business needs (Nielsen and Sort, 2013). These experiences together with good grades would enhance their CV and probability of employment upon graduation and commercialise their knowledge. 
Collaboration between universities and industry has potential profits for the both sides and is encouraged by the governments with the aim of promoting innovation and develop innovative, sustainable and prosperous regional and national economies. Nielsen et al., (2013) presents the potential benefits and barriers regarding these collaborations referring to papers by Carayol (2003), Lee (2000), Bredillet, et al., (2008). University researchers are often encouraged to start collaboration by the possibility to test the application of theory in practice, gaining funding needed to conduct research and publish papers what results in recognition within the scientific community. Companies are usually motivated to collaborate with universities by the opportunity to commercialize new knowledge in order to generate a financial gain (Siegel et $a l ., 2003)$. From the industry perspective, collaborations with universities can result in e.g., the development and transfer of technology and expertise, enhanced reputation and image, skill development, enrichment of corporate values and culture, technology testing, and recruitment and retention (Nielsen et al. 2013).

In practice there are some barriers to successful collaboration between universities and industry (Karlsson, et al., 2007; Bruneel et al., 2010). To overcome them and achieve the abovementioned benefits, it is necessary for the collaborations to be effectively managed. The paper by Nielsen et al. (2013) concerns creating tools for managing collaborative research and development projects. Authors distinguish between project management success and project success, and conclude that project management success is not causally related to project success. However, there is a link between project management success and ensuring effective use of resources in both companies and universities. According to the authors, project management is important in all stages of university-industry collaborations. The research results also indicate that it is needed to educate companies on how to work with the university. In authors' opinion it is good to start with a team of students, or a small-scale research project. There are also indications that universities could better support collaborations by structuring student contributions and supervision exercises through, (e.g., scouting, lab initiatives and solution hubs).

\section{Conclusions}

Universities are knowledge intensive organisations. They use knowledge as their main input to create knowledge as an output. Consequently, universities are predestined to facilitate intellectual capital management. Public universities have been increasingly undertaking 
Intellectual Capital Management activities in order to face pressures including lower funding, smaller number of students, globalisation of educational markets. This notion is enhanced by New Public Management (NPM) that stresses use of managerial and business methods in public sector. Our literature review illustrates that NPM may have both positive and negative impact on intellectual capital creation and management at university level. NPM tries to promote accountability by assessing performances, which establishes a stricter and more scrutinised form of administration. Contrastingly, stringent focus on results and performance evaluations sometimes leads to goal displacement understood as undertaking easily attainable goals that enable getting most out of funds allocation formulas. Intellectual Capital management faces also major challenge in commercializing (valorising) on research in various science disciplines. There are big differences between humanities and applied sciences.

Increasing number of intellectual capital measurement and reporting methods were developed specifically for universities. Examples of such methods are Wissenbilanz developed and implemented in Austria, Observatory of European Universities or the ICU Report. Building on the experience from the above mentioned intellectual capital measurement and reporting methods, the Intellectual Capital Maturity Model (ICMM) was developed. This model helps universities to evaluate the IC maturity level and increase it incrementally from one level to the next, moving from IC data collection, awareness of IC, adjustment of IC specific indicators, measurement of IC, reporting of IC, interpretation and decision making till strategy and planning. The ICMM seems to deliver comprehensive information regarding IC maturity. It creates an interesting venue for future studies investigating how this concept is implemented and operationalized by Universities in differentiated settings and various starting IC maturity levels.

Collaboration with stakeholders in order to increase Intellectual Capital for all concerned parties creates central problem in IC management. Many public universities had the tendency to inner orientation and changing this attitude takes a lot of time. In many cases also stakeholders like business and local government find it difficult to start and maintain the cooperation aimed at knowledge commercialisation. Public universities are tied closely to their regions. IC of the region and the university are often related in self-strengthening (or self-weakening) loops. In situation when the region loses it IC due to transformation of economies similar trend concerns the university. 
In the area of IC management various projects were undertaken aimed at stimulating scientists to commence actions to collaborate with partners from business and other types environment. They included: creating technology transfer centres, cooperation networks business advisory boards strengthening cooperation with graduates, as well as knowledge scouting (Wiśniewska et al, 2015, Głodek, Stawasz 2015. Such good practices enable gaining new skills needed in IC commercialisation for all stakeholders included in the project. There is a need of more cohesion and alignment in various actions aimed at IC management. Especially as some IC management practices do not succeed to become long-term embedded in organisational routines and institutions of universities.

\section{Policy of nation states should be discussed}

One more challenge in IC management at Public Universities is the collegial nature of its management. Elections of rectors, deans and senates enable independence and autonomy of communities of scholars results in politicized decision making. In some cases changes of the highest authorities lead to in rapid development or contrarily abandonment of good practices in IC management. In some countries (i.e. Sweden) in order to overcome this problem the majority of new rectors and deans that are appointed are coming outside their own university.

To conclude, more research in the area of IC management in the field of operationalizing strategies and development of skills is needed to manage IC at universities in an efficient way. It is observable that there exists a need for more research in the explaining how Universities IC is created and commercialized in the process of cooperation with stakeholders in the situation of competing needs of various stakeholders. A closer look in the process of long term embedment in organisational routines and institutions of universities of IC management is also needed. 


\section{References:}

Altenburger, O.A., Novotny-Farkas, Z. and Schaffhauser-Linzatti, M.M. (2006), "Intellectual capital reports for universities; a trial intellectual capital report at the University of Vienna", paper presented at the 29th Annual Congress of the European Accounting Association, University College Dublin, Dublin, 22-24 March

Anderson, J. C., Håkansson, H. and Johanson, J. (1994), "Dyadic Business Relationships within a Business Network Context”, Journal of Marketing, 58(4), 1-15

Arviran, N.K. (2006), "Modelling knowledge production performance of research centres with a focus on triple bottom line benchmarking", International Journal Business Performance Management, 8(4), $307-27$

Austrian Academy of Sciences (2012) "Intellectual Capital Report 2012"

Austrian Institute of Technology (2012) "Intellectual Capital Report of Austrian Institute of Technology 2012"

Benneworth, P., and Jongbloed, B. W. (2010), "Who matters to universities? A stakeholder perspective on humanities, arts and social sciences valorisation", Higher Education, 59(5), 567-588

Betz, F. (1997), “Academic government industry strategic research relationships”. Journal of Technology Transfer, 22(2), 9-16

Bezhani, I. (2010), “Intellectual capital reporting at UK universities". Journal of Intellectual Capital, 11(2), 179-207

Bogt, T. and Scapens R. W. (2012), "Performance Management in Universities: Effects of the Transition to More Qualitative Measurements System”, European Accounting Review, 21(3), 451-497

Boehm, D. N. and Hogan, T. (2014), “A jack of all trades': the role of PIs in the establishment and management of collaborative networks in scientific knowledge commercialisation". The Journal of Technology Transfer, 39(1), 134-149

Bok, D. (2009), "Universities in the marketplace: The commercialization of higher education". Princeton University Press

Bowden, J., \& Marton, F. (1998). The University of Learning: Beyond quality and competence in university education.

Bredillet, C., Walker, D. H. T., Cicmil, S., Thomas, J., and Anbari, F. (2008), „Collaborative academic/practitioner research in project management: Theory and models”, International Journal of Managing Projects in Business, 1, 17-32.

Bruneel, J., D'Este, P. and Salter, A. (2010), “Investigating the factors that diminish the barriers to university-industry collaboration”, Research Policy, 39(7), 858-868 
Burrows, J. (1999), “Going beyond labels: A framework for profiling institutional stakeholders", Contemporary Education, 70(4), 5-10

Casanueva, C. and Gallego, A. (2010), "Social capital and individual innovativeness in university research networks", Innovation: Management, Policy and Practice, 12(1), 105-117

Carayol, N. (2003), "Objectives, agreements and matching in science-industry collaborations: reassembling the pieces of the puzzle", Research Policy, 32(6), 887-908

Cavalluzzo, K. S. and Ittner, C. D. (2004), "Implementing performance measurement innovations: evidence from government”, Accounting, Organizations and Society, 29, 243-67

Corcoles Y. R., Penaver J. S. and Ponce A. T. (2011), “Intellectual capital in Spanish public universities: stakeholders' information needs", Journal of Intellectual Capital, 12(3), 356-376

Davies, I. C. (1999), "Evaluation and performance management in government", Evaluation, 5(5), 150-159

Davies, A. and Thomas, R. (2002), "Gendering and gender in public service organizations: Changing professional identities under new public management", Public Management Review, 4(4), 461-484

Dearlove, J. (2002), “A Continuing Role For Academics: The Governance of UK Universities in the Post-Dearing Era", Higher Education Quarterly, 56(3), 257-275

Delgado-Verde M., De Castro M. and Amores-Salvadó J. (2016), ”Intellectual capital and radical innovation: Exploring the quadratic effects in technology-based manufacturing firms", Technovation, $56,35-47$

Dima A., M., (2014), Handbook of Research on Trends in European Higher Education Convergence, IGI Global, USA.

Dubinskas F. A. (1988), “Making Time: Ethno graphics of High Technology Organizations”, Philadelphia, Pennsylvania: Temple University Press, 201-202

Dumay, J., Garanina, T. (2013). "Intellectual capital research: a critical examination of the third stage.” Journal of Intellectual Capital, 14(1), 10-25.

Edler, J., Mayer-Krahmer, F. and Reger, G. (2002), "Changes in the strategic management of technology: results of a global benchmarking study", $R$ and D Management, 32, 149-164

Elena, S. (2004), "Knowledge management and intellectual capital in European universities", paper presented at workshop organised by the Graduate Programme "Entering the Knowledge Society" and the Institute for Science and Technology Studies, Bielefeld University, Bielefeld, 11-13 November.

Elena, S. and Letitner K-H. (2013), "Coupling with Standardisation and Diversity: Intellectual Capital Reporting Guidelines for European Universities", in: Proceedings of the 5th European Conference on Intellectual Capital: ECIC 2013, Bilbao, Spain, L. Garcia, R. Castellanos, J. Barrutia-Guenaga (Eds.), Academic Conferences and Publishing International Limited, UK, pp. 132-141 
Emerson, R.M. (1981), “Social Exchange Theory” in: Social Psychology: Sociological Perspectives, eds. M. Rosenberg and R. Turner, New York: Basic Books, 30-65

Etzkowitz H., Webster A., (1998). "Entrepreneurial Science. The Second Academic Revolution”. In. Etzkowitz H., Webster A., Healey P. Capitalizing knowledge: New Intersections of Industry and Academia. State University of New York Press, New York, 21-46.

European Commission (2006), "Ricardis: Reporting intellectual capital to augment research, development and innovation in SMEs. Report to the Commission of the High Level" ExpertGroup on Ricardis. Available at: http://ec.europa.eu/invest-in-research/pdf/download_en/2006-2977_web1.pdf

Geuna, A. and Martin, B. R. (2003), "University research evaluation and funding: An international comparison”, Minerva, 41(4), 277-304

Gulbrandsen, M. and Smeby, J.-C., (2005), "Industry funding and university professors' research performance", Research Policy, 34, 932-950

Głodek, P., \& Stawasz, E. (2015). "Selected Aspects in The Creation of The University's Knowledge Transfer Capacity”. Optimum: studia ekonomiczne, (5 (77)), 27-41.

Gross C. M., Allen J., (2003). "Technology Transfer Entrepreneurs. A Guide to Commercializing” Federal Laboratories Innovations. Praeger, London.

Guthrie, J., Ricceri, F. and Dumay, J. (2012), "Reflections and projections: a decade of intellectual capital accounting research”, British Accounting Review, 44(2), 68-82

Hazelkorn, E. (2005), "University Research Management, Developing Research in New Institutions" OECD Publishing

Hendriks, P. H. J., Sousa C. A. A. (2012), ”Rethinking the liaison between intellectual capital Management and knowledge management", Journal of Information Science, 39(2), 270-285

Holsapple, C.W. (Ed.) (2003), “Handbook on Knowledge Management”, Springer, New York, NY.

Holton E. F. and Yamakovarenko B. (2008), "Strategic intellectual capital development defining paradigm for HRD", Human Research Development Review, 7(3), 270-291

Huggins R., Johnston A. and Stride C. (2012), "Knowledge networks and universities: Locational and organizational aspects of knowledge transfer interactions", Entrepreneurship and Regional Development, 24(7-8), 475-502

Jarratt, D., Duncan, R. and Bossomaier, T. (2014), "It's not only what you know: Simulating research networks in the UK university sector", Emergence: Complexity and Organization, 16(2), 1-28

Jolly, V. K. (1997), “Commercializing new technology”, Harvard Business School Press, Boston, 1-13 
Kaplan, R. S. and Norton, D. P. (1996), “The Balanced Scorecard: Translating Strategy into Action”, Boston: Harvard Business School Press

Kaplan, R. S. (2001), "Strategic Performance Measurement and Management in Nonprofit Organizations", Nonprofit Management and Leadership, 11(3), 353-370

Karlsson, J., Booth, S., and Odenrick, P. (2007), „Academics' strategies and obstacles in achieving collaboration between universities and SMEs", Tertiary Education and Management, 13, 187- 201.

Kianto, A., Ritala, P., Spender, J. C. and Vanhala, M. (2014), "The interaction of intellectual capital assets and knowledge management practices in organizational value creation", Journal of Intellectual Capital, 15(3), 362-375

Kok, A (2007) "Intellectual Capital Management as Part of Knowledge Management Initiatives at Institutions of Higher Learning" The Electronic Journal of Knowledge Management Volume 5 Issue 2, pp $181-192$

Koçoğlu İ., Manoğlu S. Z. İ. and İnce, H. (2009), "The relationship between firm intellectual capital and the competitive advantage", Journal of Global Strategic Management, 6, 181-208

Kok, S.-K., Douglas, A., McClelland, Bryde, D. (2010), “The Move Towards Managerialism: Perceptions of staff in "traditional" and "new" UK universities", Tertiary Education and Management, $16,2,99-113$

Lee, Y.S. (2000), “The sustainability of university-industry research collaboration: an empirical assessment”, Journal of Technology Transfer, 25(2), 111-133

Lehtimäki, H., and Peltonen, T. (2013), "Relations of power and knowledge: university-industry relations in business studies in Finland", Higher Education, 66(2), 203-216

Leitner, K.-H. (2004), "Valuation of intangibles. Intellectual capital reporting for universities: conceptual background and application for Austrian universities", Research Evaluation, $13(2), 129-40$

Leitner, K.-H. and Warden, C. (2004), "Managing and reporting knowledge-based resources and processes in research organizations: specifics, lessons learned and perspectives", Management Accounting Research, 15(1), 33-5

Leydesdorff, L. and Etzkowitz, H. (1996), "Emergence of a Triple Helix of university—industrygovernment relations", Science and public policy, 23(5), 279-286

Maritz, A. (2010), "Networking, entrepreneurship and productivity in universities", Innovation: management, policy and practice, 12, 18-25

Matusiak K. B. (2006), "Rozwój systemów wsparcia przedsiębiorczości-przesłanki, polityka i instytucje", Publishing House of the Technology and Utilization Institute, Radom, 108-109 
Matusiak K. B. and Guliński J. eds. (2010), „Rekomendacje zmian w polskim systemie transferu technologii i komercjalizacji wiedzy", Polish Agency of Enterprise Development, Warsaw

Mazzoleni R. and Nelson R. R. (1998), "The benefits and cost of strong patent protection: A contribution to the current debate", Research Policy, 27, 273-284

MERITUM (2002), Canibano, L. Garcia Ayuso, M. Sanchez, P. Chaminade, C (Eds) Guidelines for managing and reporting on intangibles (Intellectual Capital Report), Airtel-Vodafone Foundation, Madrid. Available at: http://www.pnbukh.com/files/pdf_filer/MERITUM_Guidelines.pdf

Michalak J. (2012), Kapitał intelektualny - trendy w pomiarze,prezentacji i badaniach., [w:] I. Sobańska, P. Kabalski (red.), Współczesne nurty badawcze w Rachunkowości, Wydawnictow Uniwersytetu Łódzkiego, Łódź

Mindruta, D. (2013), "Value creation in university-firm research collaborations: A matching approach", Strategic Management Journal, 34(6), 644-665

Mouwen, K. (2000), "Strategy, structure and culture of the hybrid university: Towards the university of the 21st century", Tertiary Education and Management, 6, 47-56

Mura M., Lettieri E., Spiller N. and Radaelli G. (2012), "Intellectual capital and innovative work behaviour: Opening the black box", International Journal of Engineering Business Management, 4, 110 , open access

Nielsen, C. and Sort, J. C. (2013), "Value exchange in university-industry collaborations", International Journal of Technology Transfer and Commercialisation, 12(4), 193-215

Nielsen, C., Sort, J. C., and Bentsen, M. J. (2013), "Levers of Management in University-Industry Collaborations: How project management affects value creation at different life-cycle stages of a collaboration", Tertiary Education and Management, 19(3), 246-266.

Petty, R. and Guthrie, J. (2000), "Intellectual capital literature review: measurement, reporting and management”, Journal of Intellectual Capital, 1(2), 155-176

Pollitt, C. (2002), “The new public management in international perspective”, New public management: Current trends and future prospects, 274

Potwora, W. (2011), “Innowacje (nie) innowacyjne - o współpracy nauki z gospodarką”, [in:] Zarzadzanie innowacjami. Aspekty komunikacji, finansowania, badania rynku, psychologicznych uwarunkowań, polityki innowacyjnej i infrastruktury. ed. D. M. Trzmielak, J. Żurawska, Publishing House of Silesian Institute, Opole, 278-292

Philbin, S. P. (2011), "Design and implementation of the Balanced Scorecard at a university institute", Measuring Business Excellence, 15(3), 34 - 45

Ramírez, Y., Lorduy, C. and Rojas, J.A. (2007), "Intellectual capital management in Spanish Universities”, Journal of Intellectual Capital, 8(4), 732-748 
Ramírez, Y., \& Gordillo, S. (2014). Recognition and measurement of intellectual capital in Spanish universities. Journal of Intellectual Capital, 15(1), 173-188.

Roberts, H. (1999), "The control of intangibles in the knowledge-intensive firm", paper presented at the 22nd Annual Congress of the European Accounting Association, Bordeaux

Sánchez, M. P., Castrilo, R. and Elena, S. (2006), “The Intellectual Capital Report For Universities”, in: Strategic management of University research activities, Methodological Guide, Observatory of European Universities (OEU), Prime, pp. 223-250, available at: http://www.finhed.org/media/files/01THIRD MISSION poglavlje 125 169.pdf

Sanchez, M. P. and Elena, S. (2006), "Intellectual capital in universities. Improving transparency and internal Management”, Journal of Intellectual Capital, 7(4), 529-548

Sanchez, P., Elena, S. and Castrillo, R. (2009), "Intellectual capital dynamics in universities: a reporting model", Journal of Intellectual Capital, 10(2), 307-324

Secundo, G., Elena-Perez, S., Martinaitis, Ž. and Leitner, K.-H. (2015), “An intellectual capital maturity model (ICMM) to improve strategic management in European universities: A dynamic approach" Journal of Intellectual Capital, 16(2), 419-442

Secundo, G., Margheritam, A., Elia, G. and Passiante, G. (2010), "Intangible assets in higher education and research: mission, performance or both?", Journal of Intellectual Capital, 11(2), 140157

Siegel, D. S., Waldman, D. A., Atwater, L. E. and Link, A. N. (2003), "Commercial knowledge transfers from universities to firms: improving the effectiveness of university-industry collaboration", Journal of High Technology Management Research, 14(1), 111-133

Slaughter, S. and Leslie, L. (2001), "Expanding and elaborating the concept of academic capitalism", Organization, 8(2), 154-161

Sopińska, A. (2014), "Wiedza i kapitał intelektualny w nowych typach organizacji - w organizacjach sieciowych", Research Papers of the Wroclaw University of Economics / Prace Naukowe Uniwersytetu Ekonomicznego we Wroclawiu, 340, 788-798

Speckbacher, G. (2003), "Performance Management in Nonprofit Organizations", Nonprofit Management and Leadership, 13(3), 267-281

Teirlinck, P. and Spithoven, A. (2015), "How the nature of networks determines the outcome of publicly funded university research projects”, Research Evaluation, 24(2), 158-170

Pogue G. P., Lorenzini F., Thomson K., (2014). Technology Transfer and the Innovation Reef. In. Trzmielak D. M. Gibson D. V., International Cases on Innovation, knowledge and technology transfer. University of Łódź Press, Łódź, 13-38. 
Trzmielak D. M., (2013). Komercjalizacja wiedzy i technologii - determinanty i strategie. Wydawnictwo Uniwersytetu Łódzkiego, Łódź 2013.

Viale R., (2010). Knowledge - driven Capitalization of Knowledge. In. Viale R., Etzkowitz, The Capitalization of Knowledge. A triple Helix of University - industry - government. Edward Elgar Publishing, Northampton, 31-74.

Van Dierdonck, R., Debackere, K. and Engelen, B. (1990), "University-industry relationships: How does the Belgian academic community feel about it?", Research Policy, 19, 551-566

Warden, C. (2003), "Managing and reporting intellectual capital: new strategic challenges for HEROs", IP Helpdesk Bulletin, No. 8, April-May

Warden, C. (2004), "New modes of self-description: universities reaction in a changing environment", paper presented at the workshop Towards a Multiversity? Universities between National Traditions and Global Trends in Higher Education, Bielefeld, 11-13 November

Wiedenhofer, R. Bornemann, M .(2016); "Bridging the gap from Intellectual Capital to Quality and Strategic Management in Higher Educational Institutions' Governance - Experiences from Austria"Proceedings of the 12th EIASM Interdisciplinary Workshop on ,Intangibles, Intellectual Capital \& Extra-Financial Information"

Wiśniewska, M., Głodek, P., \& Trzmielak, D. (2015) “Wdrażanie scoutingu wiedzy w polskiej uczelni wyższej. Aspekty praktyczne.” Wydawnictwo Uniwersytetu Łódzkiego

Wissema J. G. (2009),"Uniwersytet Trzeciej Generacji Uczelnia XXI wieku”, Zante Publishing House, Zębice, 28-33

Yassen S. G., Dajani D., Hasan Y., (2016). "The Impact of Intellectual Capital on the competitive Advantage: Applied Study in Jordanian Telecommunication Companies." Computers in Human Behavior, Vol. 62, 168-175.

Zucker, L. G., Darby, M. R. and Armstrong, J. S. (2002), "Commercializing knowledge: University science, knowledge capture, and firm performance in biotechnology”, Management Science, 48(1), $138-153$

\footnotetext{
${ }^{1}$ For further readings on networks in universities see further: Maritz, (2010); Huggins et al., (2012); Lehtimäki and Peltonen, (2013); Mindrutta, (2013); Teirlinck and Spithoven, (2015).
} 